\title{
Pengaruh Pembelajaran Tematik dengan Menerapkan Pendekatan Lingkungan terhadap Pengetahuan Siswa Sekolah Dasar Negeri Seluma tentang Lingkungan Sahabat Kita
}

\author{
Ansyori Gunawan \\ PGSD FKIP Universitas Bengkulu \\ ansyori.pgsdunib@gmail.com
}

\section{Sri Dadi}

PGSD FKIP Universitas Bengkulu

srid3154@gmail.com

\section{Dwi Anggraini \\ PGSD FKIP Universitas Bengkulu \\ dwianggraini@unib.ac.id}

\begin{abstract}
The purpose of this study is to determine the effect of thematic learning by applying an environmental approach to the knowledge of Seluma Primary-School students about the Our Friends Environment. The research used is the only matching pretest-posttest control group design. The populations are all grade V students of SDN Seluma in the academic year 2017/2018. The research samples are grade V students of SDN 01 and SDN 13 Seluma. The instrument used is a test sheet to measure students' knowledge about the environment of our friends. The results of the research data are analyzed inferentially by independent sample t-test. The results of the study obtained a significance value (2-tailed) is lower than 0.025 . The conclusion of this study is that there is a significant influence of thematic learning by applying an environmental approach to the knowledge of SDN Seluma students about the environment of our friends.
\end{abstract}

Keywords: Thematic Learning, Environmental Education, Student Knowledge.

\begin{abstract}
Abstrak
Tujuan dari penelitian ini adalah untuk mengetahui pengaruh pembelajaran tematik dengan menerapkan pendekatan lingkungan terhadap pengetahuan siswa Sekolah Dasar Seluma tentang Lingkungan Teman Kita. Penelitian yang digunakan adalah satu-satunya desain kelompok kontrol pretest-posttest yang cocok. Populasi adalah semua siswa kelas V SDN Seluma pada tahun akademik 2017/2018. Sampel
\end{abstract}


penelitian adalah siswa kelas V SDN 01 dan SDN 13 Seluma. Instrumen yang digunakan adalah lembar tes untuk mengukur pengetahuan siswa tentang lingkungan teman-teman kita. Hasil data penelitian dianalisis secara inferensial dengan uji-t sampel independen. Hasil penelitian diperoleh nilai signifikansi (2- tailed) lebih rendah dari 0,025. Kesimpulan dari penelitian ini adalah bahwa ada pengaruh yang signifikan dari pembelajaran tematik dengan menerapkan pendekatan lingkungan terhadap pengetahuan siswa SDN Seluma tentang lingkungan temanteman kita.

\section{Kata kunci: Pembelajaran Tematik, Pendidikan Lingkungan, Pengetahuan Siswa.}

\section{Pendahuluan}

Propinsi Bengkulu terletak pada $2^{\circ}-5^{\circ}$ Lintang Selatan dan $101^{\circ}-104^{\circ}$ Bujur Timur. Secara geografis, propinsi Bengkulu mempunyai luas wilayah $19.789 \mathrm{~km}^{2}$ yang terdiri dari jalur, dataran pantai dengan ketinggian 1-100 m, jalur lereng pegunungan dengan ketinggian 101-1000 m dan jalur pegunungan dengan ketinggian 1001-2000 m di atas permukaan laut. Selain itu, propinsi Bengkulu juga mempunyai lingkungan alam dengan iklim bercurah hujan berkisaran 2253-5946 mm dan suhu kelembaban udara berkisar antara $18^{\circ}-36^{\circ} \mathrm{c}$, serta mempunyai susunan tanah dengan formasi yang banyak mengandung bahan tambang (Depdikbud. 1997/1998).

Curah hujan yang tinggi bisa menyebabkan banjir di suatu daerah. Faktor-faktor yang dapat menyebabkan banjir bisa datang karena kegiatan manusia baik secara langsung maupun tidak langsung berpengaruh terhadap keseimbangan alam. Contohnya : (1) kebiasaan membuang sampah di selokan/siring, (2) penebangan pohon sembarangan, (3) penambangan pasir, dan (4) pembangunan gedung dan jalan beton di daerah resapan air (Irene, 2015). Keadaan lingkungan alam dan iklim di atas perlu diketahui oleh masyarakat yang tinggal di Bengkulu, khususnya siswa sekolah dasar. Oleh karena itu, sekolah dasar hendaknya memberikan bekal kepada siswa tentang keadaan lingkungan alam dan iklim bercurah hujan tinggi tersebut kepada siswa sekolah dasar. Bekal pengetahuan tersebut sangat bermanfaat bagi siswa dalam mempersiapkan diri pada kehidupan di masyarakat. Siswa akan merasa senang belajar karena materi yang dipelajari berkaitan dengan lingkungannya yang ada di sekitar siswa. Namun kenyataan di lapangan sekolah dasar di Kabupaten Seluma belum melakukan hal tersebut. Guru belum mengembangkan materi secara maksimal sehingga pengetahuan siswa tentang peristiwa di lingkungan sekitar belum dipahami. Oleh karena itu perlu dilakukan penelitian tentang pemanfaatan lingkungan sebagai sumber belajar dengan cara menerapkan pendekatan lingkungan.

Berdasarkan hasil penelitian Dadi (2015) permasalahan pengembangan karakter di SD kota Bengkulu sebagai berikut: (1) guru kurang mendorong siswa untuk aktif bertingkah laku sesuai dengan nilai-nilai yang berlaku, (2) guru kurang memotivasi siswa untuk menerapkan sikap, perilaku, dan nilai-nilai karakter, (3) guru belum menciptakan pengalaman belajar yang dibutuhkan siswa, (4) satu-satunya sumber belajar adalah buku paket/penunjang, dan (5) hasil belajar siswa belum optimal (ratarata 64 dengan ketuntasan 66\%). Permasalahan tersebut dapat diatasi melalui pembelajaran tematik dengan menerapkan pendekatan lingkungan.

Salah satu pendekatan pembelajaran yang dapat menarik minat siswa dan meningkatkan keterlibatan siswa yaitu pendekatan lingkungan, yang mana pendekatan ini memanfaatkan lingkungan sebagai sumber belajar. Lingkungan 
belajar terdiri dari lingkungan sosial, personal, alam dan kultural (Dadi, 2009). Menurut Badeni (2016) lingkungan sosial terdiri dari lingkungan fisik, sumber daya masayarakat, dan hubungan sosial. Efendi (2016) dalam tulisannya mengungkapkan bahwa desain pendidikan berbasis masyarakat dan budayaharus mengacu pada pembebasan, penyadaran, dan kreativitas.

Kemendikbud (2014) menyatakan bahwa pembelajaran tematik terpadu merupakan pembelajaran yang memadukan beberapa mata pelajaran dalam satu kali pertemuan. Pemaduan ini diikat dengan tema sehingga memberikan pengalaman bermakna bagi siswa. Hal ini sejalan dengan Koeriyah dan Mawardi (2018) dalam penelitiannya menyimpulkan bahwa meningkatnya kebermaknaan belajar ditunjukkan oleh kategori sangat bermakna, dengan persentase pada siklus 1 sebesar $87,5 \%$, meningkat pada siklus 2 menjadi 95\%. Fokus pembelajaran tematik diarahkan kepada pembahasan tema-tema yang dekat dengan kehidupan siswa. Salah satu tema yang ada di kelas V adalah Lingkungan Sahabat Kita. Suatu peristiwa yang terjadi di lingkungan sekitar siswa diantaranya adalah peristiwa banjir. Berdasarkan uraian diatas, maka tujuan penelitian ini adalah " Mengetahui Pengaruh Pembelajaran Tematik Dengan Menerapkan Pendekatan Lingkungan Terhadap Pengetahuan Siswa Sekolah Dasar Negeri Seluma Tentang Lingkungan Sahabat Kita"

\section{Metode}

Adapun Desain penelitian ini adalah the matching only pretest-posttest control group design (Fraenkel dan Norman dalam Winarni: 2018) dapat dilihat pada gambar berikut.

\begin{tabular}{|l|l|l|l|}
\hline $\mathrm{O}_{1}$ & $\mathrm{M}$ & $\mathrm{X}$ & $\mathrm{O}_{2}$ \\
\hline $\mathrm{O}_{3}$ & $\mathrm{M}$ & $\mathrm{C}$ & $\mathrm{O}_{4}$ \\
\hline
\end{tabular}

Gambar 1. Desain Penelitian

Keterangan:

$\mathrm{O}_{1} \quad$ : Pretest Untuk Kelas Eksperimen

$\mathrm{O}_{2} \quad$ : Posttest Untuk Kelas Eksperimen

M : Pencocokan Subyek

$\mathrm{X}$ : Pembelajaran Tematik dengan menerapkan pendekatan lingkungan

$\mathrm{O}_{3} \quad$ : Pretest Untuk Kelas Kontrol

$\mathrm{O}_{4} \quad$ : Posttest Untuk Kelas Kontrol

$\mathrm{C} \quad$ : Pembelajaran Tematik dengan menggunakan media gambar

Populasi dalam penelitian ini adalah seluruh siswa kelas V SDN di Kabupaten Seluma Tahun Ajaran 2017/2018. Sampel penelitiannya adalah siswa kelas V SDN 01 dan SDN 13 Seluma. Dalam menentukan kelas eksperimen dan kontrol dilakukan secara cluster random sampling. Menurut Winarni (2018) teknik cluster random sampling digunakan jika dijumpai populasi yang heterogen di mana sub populasi merupakan suatu kelompok yang mempunyai sifat heterogen, sedangkan dalam stratifikasi sampel tiap sub populasinya homogen.

Instrumen yang digunakan dalam penelitian ini adalah lembar tes untuk mengukur pengetahuan siswa tentang Lingkungan Sahabat Kita. Lembar tes yang digunakan dalam penelitian ini berupa berupa tes tertulis yang berbentuk essay. Lembar tes sudah dilakukan uji coba pada siswa di luar sampel, tetapi pada kelompok yang telah mempelajari materi yang akan dijadikan penelitian.

Data yang diperoleh dalam penelitian ini dianalisis dengan menggunakan SPSS. Pengolahan dan analisis data yang dilakukan meliputi uji prasyarat dan pengujian hipotesis. 


\section{Hasil}

Kompetensi Dasar dan Indikator pada kedua kelas sama yaitu : (1) mata pelajaran Bahasa Indonesia, kompetensi dasar "menggali informasi dari teks laporan buku tentang makanan dan rantai makanan, kesehatan manusia, keseimbangan ekosistem, serta alam dan pengaruh kegiatan manusia dengan bantuan guru dan teman dalam bahasa Indonesia lisan dan tulisan dengan memilih dan memilah kosa kata baku " dengan Indikator " menggali informasi tentang penyebab dan terjadinya banjir". (2) mata pelajaran IPA, kompetensi dasar " mengidentifikasi perubahan yang terjadi di alam, hubungannya dengan penggunaan sumber daya alam, dan pengaruh kegiatan manusia terhadap keseimbangan lingkungan " dengan indikator " menjelaskan kegiatan manusia yang dapat menyebabkan banjir". (3) mata pelajaran Matematika, kompetansi dasar" memahami arti rata-rata, median dan modus dari sekumpulan data-data" dengan indikator" mengurutkan data tentang luas lahan".

Sumber belajar yang digunakan untuk kelas eksperimen adalah nara sumber/penduduk dan rumah penduduk yang terdapat di lokasi banjir. Sedangkan sumber belajar untuk kelas control adalah media gambar.

Berdasarkan perbedaan sumber belajar dan kegiatan siswa antara kelas eksperimen dan control, maka berakibat pada perbedaan hasil belajar pengetahuan tentang lingkungan sahabat kita yang diukur pada saat postest. Namun sebelum diberi perlakuan kedua kelas baik kelas eksperimen maupun kelas control diberi pretest terlebih dahulu. Adapun hasil pretest dan postest siswa pada kelas eksperimen dengan menerapkan pendekatan lingkungan disajikan pada tabel1 berikut ini.

Tabel 1. Hasil Pretest dan Postest Pada Kelas Eksperimen

\begin{tabular}{|c|c|c|c|c|c|c|c|}
\hline \multirow[b]{2}{*}{ No } & \multirow[b]{2}{*}{ Keterangan } & \multicolumn{2}{|c|}{ Bahasa Indonesia } & \multicolumn{2}{|c|}{ IPA } & \multicolumn{2}{|c|}{ Matematika } \\
\hline & & Pretest & Postest & $\overline{\text { Pretest }}$ & Postest & Pretest & Postest \\
\hline 1 & Nilai Terendah & 30,000 & 70,000 & 30,000 & 70,000 & 30,000 & 70,000 \\
\hline 2 & Nilai Tertinggi & 60,000 & 90,000 & 60,000 & 90,000 & 70,000 & 90,000 \\
\hline 3 & Rata-Rata & 44,583 & 83,750 & 49,583 & 82,083 & 57,083 & 78,333 \\
\hline
\end{tabular}

Berdasarkan tabel 1, peningkatan nilai rata-rata dari pretest ke posttest yaitu : (1) mata pelajaran Bahasa Indonesia nilai rata-rata pretest sebesar 44,583 sedangkan posttest sebesar 83,750 sehingga terjadi peningkatan sebesar 39,167 (2) mata pelajaran IPA nilai rata-rata pretest sebesar 49,583 sedangkan posttest sebesar 82,083 sehingga terjadi peningkatan sebesar 32,500, dan (3) mata pelajaran matematika nilai rata-rata pretest sebesar 57,083 sedangkan posttest sebesar 78,333, sehingga terjadi peningkatan sebesar 21,250. Adapun hasil pretest dan posttest siswa pada kelas control dengan menggunakan media gambar disajikan pada tabel 2 berikut ini.

Tabel 2. Hasil Pretest dan postest pada kelas control

\begin{tabular}{|c|c|c|c|c|c|c|c|}
\hline \multirow[t]{2}{*}{ No } & \multirow[t]{2}{*}{ Keterangan } & \multicolumn{2}{|c|}{$\begin{array}{l}\text { Bahasa } \\
\text { Indonesia }\end{array}$} & \multicolumn{2}{|c|}{ IPA } & \multicolumn{2}{|c|}{ Matematika } \\
\hline & & Pretest & Postest & Pretest & Postest & Pretest & Postest \\
\hline 1 & Nilai Terendah & 30,000 & 70,000 & 30,000 & 70,000 & 30,000 & 55,000 \\
\hline 2 & Nilai Tertinggi & 60,000 & 80,000 & 70,000 & 85,000 & 70,000 & 80,000 \\
\hline 3 & Rata-Rata & 39,411 & 74,117 & 46,764 & 75,588 & 48,235 & 65,647 \\
\hline
\end{tabular}

Berdasarkan tabel 2, peningkatan nilai rata-rata dari pretest ke posttest yaitu : (1) mata pelajaran Bahasa Indonesia nilai rata-rata pretest sebesar 39,411 sedangkan posttest sebesar 74,117 sehingga terjadi peningkatan sebesar 34,706 (2) mata pelajaran IPA nilai rata-rata pretest sebesar 46,764 sedangkan posttest sebesar 75,588 sehingga terjadi peningkatan sebesar 28,824 , dan (3) mata pelajaran matematika nilai rata-rata pretest sebesar 48,235 sedangkan posttest sebesar 65,647 , sehingga terjadi peningkatan sebesar 17,412 . 
Hasil penelitian menunjukkan bahwa pelaksanaan pembelajaran dengan menerapkan pendekatan lingkungan, dapat meningkatkan hasil belajar pengetahuan siswa. Pada kelas ekspiremen antara pretest dan posttest terjadi peningkatan sebesar 39,167 untuk mata pelajaran bahasa Indonesia; 32,500 untuk mata pelajaran IPA; dan 21,250 untuk mata pelajaran matematika. Sedangkan pada kelas control antara pretest dan posttest terjadi peningkatan sebesar 34,706 untuk mata pelajaran bahasa Indonesia; 28,824 untuk mata pelajaran IPA; dan 17,412 untuk mata pelajaran matematika.

Data pretest baik kelas ekspiremen maupun kelas control dianalisis dengan menggunakan uji independent sampel t-test. Sebelum dianalisis dengan uji independent sample t-test dilakukan uji normalitas dan homogenitas. Untuk mata pelajaran bahasa Indonesia nilai signifikansi normalitas kelas eksperimen sebesar 0,010 (berdistribusi tidak normal), sedangkan kelas control sebesar 0,010(berdistribusi tidak normal). Kemudian nilai signifikansi homogenitas kedua kelas sampel sebesar 0,081 (homogen). Setelah itu dilakukan uji hipotesis dengan menggunakan uji Mann Whitney U dan diperoleh nilai signifikansi (2-tailed) sebesar $0,121>0,025$, artinya tidak ada perbedaan kemampuan awal antara kelas eksperimen dan control.

Pada mata pelajaran IPA nilai signifikansi normalitas kelas eksperimen sebesar 0,004 (berdistribusi tidak normal), sedangkan kelas control sebesar 0,085 (berdistribusi normal). Kemudian nilai signifikansi homogenitas kedua kelas sampel sebesar 0,438 (homogen). Setelah itu dilakukan uji hipotesis dengan menggunakan uji Mann Whitney U dan diperoleh nilai signifikansi (2-tailed) sebesar 0,288>0,025, artinya tidak ada perbedaan kemampuan awal antara kelas eksperimen dan control.

Pada mata pelajaran matematika nilai signifikansi normalitas kelas eksperimen sebesar 0,018 (berdistribusi tidak normal), sedangkan kelas control sebesar 0,033 (berdistribusi tidak normal). Kemudian nilai signifikansi homogenitas kedua kelas sampel sebesar 0,224 (homogen). Setelah itu dilakukan uji hipotesis dengan menggunakan uji Mann Whitney $\mathrm{U}$ dan diperoleh nilai signifikansi (2-tailed) sebesar $0,062>0,025$, artinya tidak ada perbedaan kemampuan awal antara kelas eksperimen dan control.

Data posttest baik kelas eksperimen maupun kelas control dianalisis dengan menggunakan uji independent sampel t-test. Sebelum dianalisis dengan uji independent sampel t-test dilakukan uji normalitas dan homogenitas. Untuk mata pelajaran bahasa Indonesia nilai signifikansi normalitas kelas eksperimen sebesar 0,002 (berdistribusi tidak normal), sedangkan kelas control sebesar 0,007 (berdistribusi tidak normal). Kemudian nilai signifikansi homogenitas kedua kelas sampel sebesar 0,027 (tidak homogen). Setelah itu dilakukan uji hipotesis dengan menggunakan uji Mann Whitney $U$ dan diperoleh nilai signifikansi (2-tailed) sebesar $0,000<0,025$, artinya ada perbedaan hasil belajar pengetahuan siswa antara kelas eksperimen dan control. Nilai signifikansi (2-tailed) sebesar $0,000<0,025$, ini menunjukkan bahwa $\mathrm{H}_{\mathrm{a}}$ diterima, artinya terdapat pengaruh pembelajaran tematik dengan menerapkan pendekatan lingkungan terhadap hasil belajar pengetahuan siswa Sekolah Dasar Negeri Seluma tentang Lingkungan Sahabat Kita.

Pada mata pelajaran IPA nilai signifikansi normalitas kelas eksperimen sebesar 0,003 (berdistribusi tidak normal), sedangkan kelas control sebesar 0,024 (berdistribusi tidak normal). Kemudian nilai signifikansi homogenitas kedua kelas sampel sebesar 0,019 (tidak homogen). Setelah itu dilakukan uji hipotesis dengan menggunakan uji Mann Whitney U dan diperoleh nilai signifikansi (2-tailed) sebesar 0,004<0,025, artinya ada perbedaan hasil belajar pengetahuan siswa antara kelas eksperimen dan control. Nilai signifikansi (2-tailed) sebesar $0,004<0,025$, ini menunjukkan bahwa $\mathrm{H}_{a}$ 
diterima, artinya terdapat pengaruh pembelajaran tematik dengan menerapkan pendekatan lingkungan terhadap hasil belajar pengetahuan siswa Sekolah Dasar Negeri Seluma tentang Lingkungan Sahabat Kita.

Pada mata pelajaran Matematika nilai signifikansi normalitas kelas eksperimen sebesar 0,014 (berdistribusi tidak normal), sedangkan kelas control sebesar 0,236 (berdistribusi normal). Kemudian nilai signifikansi homogenitas kedua kelas sampel sebesar 0,261 (homogen). Setelah itu dilakukan uji hipotesis dengan menggunakan uji Mann Whitney $U$ dan diperoleh nilai signifikansi (2.tailed) sebesar $0,000<0,025$, artinya ada perbedaan hasil belajar pengetahuan siswa antara kelas eksperimen dan control. Nilai signifikansi (2-tailed) sebesar $0,000<0,025$, ini menunjukkan bahwa $\mathrm{H}_{a}$ diterima, artinya terdapat pengaruh pembelajaran tematik dengan menerapkan pendekatan lingkungan terhadap hasil belajar pengetahuan siswa Sekolah Dasar Negeri Seluma tentang Lingkungan Sahabat Kita.

Berdasarkan uraian di atas dapat disimpulkan bahwa pelaksanaan pembelajaran dengan menerapkan pendekatan lingkungan pada ketiga mata pelajaran yaitu Bahasa Indonesia, IPA dan Matematika berpengaruh terhadap hasil belajar pengetahuan siswa Sekolah Dasar Negeri Seluma tentang Lingkungan Sahabat Kita.

\section{Pembahasan}

Berdasarkan hasil penelitian dan uji hipotesis yang telah dilakukan menunjukkan bahwa pembelajaran tematik dengan menerapkan pendekatan lingkungan memberikan pengaruh terhadap hasil belajar pengetahuan siswa Sekolah Dasar Negeri Seluma tentang Lingkungan Sahabat Kita. Hal ini ditunjukkan dari hasil belajar pengetahuan siswa pada kelas eksperimen lebih baik dari kelas control. Pada mata pelajaran bahasa Indonesia nilai rata-rata posttest kelas eksperimen sebesar 83,750 , sedangkan kelas control sebesar 74,117. Selisih nilai kedua kelas tersebut sebesar 9,633. Mata pelajaran IPA nilai posttest kelas eksperimen sebesar 82,083, sedangkan kelas control sebesar 75,588. Selisih nilai kedua kelas tersesbut sebesar 6,495. Mata pelajaran matematika nilai posttest kelas eksperimen sebesar 78,333, sedangkan kelas control sebesar 65,647. Selisih nilai kedua kelas tersebut sebesar 12,686 .

Hasil data posttest dianalisis menggunakan uji independent sampel t-test. Untuk mata pelajaran bahasa Indonesia diperoleh nilai signifikansi (2.tailed) sebesar 0,000; IPA sebesar 0,004; dan matematika 0,000. Hal ini menunjukkan bahwa nilai signifikansi (2.taled) baik mata pelajaran bahasa Indonesia, IPA dan Matematika lebih kecil dari 0,025 , ini menunjukkan bahwa $\mathrm{H}_{\mathrm{a}}$ diterima, artinya terdapat pengaruh pembelajaran tematik dengan menerapkan pendekatan lingkungan terhadap hasil belajar pengetahuan siswa Sekolah Dasar Negeri Seluma tentang Lingkungan Sahabat Kita. Hal ini sejalan dengan hasil penelitian Hendarwati (2013) yaitu pemanfaatan lingkungan sebagai sumber belajar dengan metode inkuiri pada mata pelajaran IPS lebih baik dibadingkan dengan pembelajaran menggunakan metode ceramah di SD 1 Sribit Delanggu.

Adanya pengaruh yang signifikan terhadap hasil belajar pengetahuan siswa karena dengan menerapkan pendekatan lingkungan pada pembelajaran tematik siswa lebih aktif dalam pembelajaran dan siswa secara langsung mencari data di lapangan. Di samping itu kegiatan pembelajaran juga menarik perhatian siswa karena apa yang dipelajari diangkat dari lingkungan. Hal ini sejalan dengan hasil penelitian Dalifa dan Winarni (2015) yaitu penggunaan pendekatan lingkungan pada mata pelajaran IPA PLH dan Biodiversity bisa meningkatkan aktivitas guru, siswa, pemahaman konsep dan kesadaran terhadap lingkungan serta pelestarian biodiversity. Siswa juga mampu memecahkan masalah yang terjadi di lingkungan berdasarkan keterampilan, kreatif 
berfikir kritis. Hal ini sejalan dengan hasil penelitian Neka, Marhaeni dan Suastra (2015) yaitu siswa yang menggunakan model pembelajaran inkuiri terbimbing berbasis lingkungan memiliki keterampilan berpikir kreatif dan penguasaan konsep IPA kelas V SD lebih baik dibandingkan dengan siswa yang menggunakan model pembelajaran langsung. Lebih lanjut Bruner dalam Mulyani (2009) menyatakan bahwa pembelajaran harus berhubungan dengan pengalaman serta konteks lingkungan siswa sehingga mendorong siswa untuk belajar.

Pada kelas eksperimen siswa tampak bersemangat dan penuh ingin tahu terhadap materi pelajaran. Hal ini ditunjukkan saat siswa melakukan wawancara dengan nara sumber terlihat serius dan teliti dalam menulis hasil wawancara. Dengan demikian dapat memotivasi dalam pembelajaran. Pernyataan tersebut sesuai dengan hasil penelitian Febriyanti (2015) bahwa terdapat hubungan anatar lingkungan belajar dengan motivasi belajar sisiwa SD Negeri Gugus III Kota Bengkulu.

Pelaksanaan pembelajaran tematik dengan membawa siswa ke lingkungan untuk melakukan wawancara dengan nara sumber dan melakukan aktivitas pengukuran panjang dan lebar rumah penduduk dapat mengembangkan karakter siswa, antara lain bersahabat, percaya diri, teliti, rasa ingin tahu, kritis, dan kreatif. Hal ini sejalan dengan hasil penelitian Wurdjinem dan Dadi (2014) bahwa penerapan metode problem solving melalui pemanfaatan lingkungan dapat mengembangkan karakter mahasiswa antara lain karakter bersahabat, kritis, kreatif, rasa ingin tahu, dan teliti.

\section{Simpulan}

Berdasarkan hasil penelitian yang telah dikemukakan, maka dapat diambil kesimpulan bahwa "Terdapat pengaruh pembelajaran tematik dengan menerapkan pendekatan lingkungan terhadap pengetahuan siswa Sekolah Dasar Negeri Seluma tentang lingkungan Sahabat Kita". Hal ini ditunjukkan pada pembelajaran tematik diperoleh nilai signifikansi (2-taled) lebih kecil dari 0,025.

\section{Ucapan Terima Kasih}

Ucapan terima kasih disampaikan kepada: (1) Direktorat Jenderal Penelitian dan Pengembangan Teknologi Penguatan Riset dan Pengembangan di Bidang Penelitian dan Pengabdian kepada Masyarakat yang telah memberikan Dana Penelitian Strategis Nasional Institusi tahun II/ 2018, (2) Rektor Universitas Bengkulu melalui Lembaga Penelitian dan Pengabdian Masyarakat yang telah memfasilitasi pelaksanaan penelitian, baik secara teknik maupun administratif.

\section{Referensi}

Ismail, A., Tiwi, daan Salmi (2016). Pendidikan Berbasis Lingkungan Alam Menghadapi Tantangan Global Warming. In Prosiding Seminar Nasional Pendidikan 2016 Prodi PGSD FKIP Universitas Bengkulu: 18-26

Efendi, A. (2016). Pendidikan Berbasis Lingkungan Budaya. In Prosiding Seminar Nasional Pendidikan 2016 Prodi PGSD FKIP Universitas Bengkulu: 14-17

Febriyanti, Arida (2015). Hubungan Suasana Lingkungan Belajar dengan Motivasi Belajar Siswa SD Negeri Gugus III Kota Bengkulu. In Prosiding Seminar Nasional Pendidikan 2015 PGSD FKIP Universitas Bengkulu: 322-328 
Dadi, S. (2007). Pemanfaatan Model Kelas Sebagai Penerapan Pendekatan Pembelajaran Tematik di Kelas IV SDN 27 Kota Bengkulu. Laporan Penelitian Due-Like. Universitas Bengkulu.

Dadi, S. (2009). Pengembangan Pembelajaran IPS SD. Bengkulu: PGSD FKIP Universitas Bengkulu.

Badeni. (2016). Pendidikan Berbasis Lingkungan Sosial. In Prosiding Seminar Nasional Pendidikan 2016 Prodi PGSD FKIP Universitas Bengkulu.

Depdikbud. (1978/1980). Pertenunan Tradisional Daerah Bengkulu. Bengkulu. Proyek Pengembangan Permusiuman Bengkulu.

Dalifa dan Winarni, E. W. (2015). Pengembangan Model PLH Terintegrasi dalam IPA Menggunakan Pendekatan Lingkungan untuk Pelestarian Biodiversity Bagi Siswa SD. In Prosiding Seminar Nasional Pendidikan 2015 Prodi PGSD FKIP Universitas Bengkulu.

Hendarwati, E. (2013). Pengaruh Pemanfaatan Lingkungan Sebagai Sumber Belajar melalui Metode Inkuiri terhadap Hasil Belajar Siswa SDN 1 Sribit Delanggu pada Pembelajaran IPS. Jurnal Pedagogia, 2 (1), 59-70.

Neka, I. K., Marhaeni, A. N., \& Suastra, I. W. (2015). Pengaruh Model Pembelajaran Inkuiri Terbimbing Berbasis Lingkungan Terhadap Keterampilan Berpikir Kreatif dan Penguasaan Konsep IPA Kelas V SD Gugus VIII Kecamatan Abang. PENDASI: Jurnal Pendidikan Dasar Indonesia, 5(1).

Kemendikbud. (2014). Materi Pelatihan Guru Implementasi Kurikulum 2013. Jakarta : Kemendikbud.

Dadi, S. (2015). Pemanfaatan Model kelas sebagai Sumber Belajar dalam Pembelajaran IPS untuk Mengembangkan karakter dan kecerdasan Emosional Siswa Kelas IV Sekolah Dasar Negeri 74 Kota Bengkulu. Jurnal PGSD: Jurnal Ilmiah Pendidikan Guru Sekolah Dasar, 8(1), 1-6.

Koeriyah, N. \& Mawardi. (2018). Penerapan Desain Pembelajaran Tematik Integratif Alternatif Berbasis Kearifan Lokal untuk Meningkatkan Hasil dan Kebermaknaan Belajar. Mimbar Sekolah Dasar, 5(2), 63-74.

Winarni, E. W. (2018). Teori dan Praktik Penelitian Kuantitatif Kualitatif, PTK, dan R\&D. Jakarta: Bumi Aksara.

Wurdjinem \& Dadi, S. (2014). Penerapan Metode Pembelajaran Problem Solving Melalui Pemanfaatan Lingkungan untuk Meningkatkan Hasil Belajar dan Mengembangkan Karakter Mahasiswa pada Perkuliahan Konsep Dasar IPS Di PGSD FKIP UNIB. Jurnal PGSD: Jurnal Ilmiah Pendidikan Guru Sekolah Dasar, 7(13), 153-157. 